\title{
Supervision Of Schools Head Master In Digital Era To Improve Teacher Performance
}

\author{
M. Basir Hasibuan ${ }^{1}$, Paningkat Siburian ${ }^{2}$ \\ Head of Branch Education Office Sunggal North Sumatra Province, Indonesia ${ }^{1}$, \\ Professor at Universitas Negeri Medan North Sumatra, Indonesia ${ }^{2}$
}

\begin{abstract}
In the current millennial era, principals need new knowledge and skills to lead effectively both in terms of cost and authority. As a teaching leader (instructional leadership) the principal is responsible for mobilizing and directing all the potential of teachers to achieve educational goals in schools. Related to the principal's duties, the principal's position as school administrator, teaching leader, and supervisor. the principal as a suvervisor must be realized in the ability of the compiler and implement the education supervision program and utilize the results. The ability to compile educational supervision programs must be realized in the preparation of classroom supervision programs, development of supervision programs for extra-curricular activities, development of library, laboratory, and exam supervision programs. As teaching leaders, principals must be able to mobilize the potential of school personnel including staff and teacher development activities, carrying out evaluation programs for teachers and staff. As the principal's supervisor has the task of providing professional technical assistance to teachers in planning, implementing and evaluating teaching so that learning objectives can be achieved optimally. In carrying out their duties as supervisors, the principal can choose the right approach according to the problems faced by the teacher and needs to pay attention to the level of teacher maturity. Principals of senior high schools / vocational schools in Medan Sunggal Subdistrict, Deliserdang Regency, North Sumatra, conducted a clinical approach. From the research results it is proven that the clinical approach is proven to be able to improve the quality of teaching of teachers in SMA/SMK Sunggal sub-district, Deli Serdang Regency.
\end{abstract}

Keywords: suvervison, digital era, teacher performance, high school

\section{Introduction}

Description of 1945 Constitution regarding education is outlined in Law No. 20, 2003. Article 3 states, "National education functions to develop capabilities and shape the character and civilization of a dignified nation in the context of educating the life of the nation, aiming at developing the potential of learners to become human beings who believe in and have faith in God Almighty, have good morals , healthy, knowledgeable, capable, creative, independent, and be a democratic and responsible citizen". 
The achievement of educational goals is inseparable from an educator or instructor because without the teacher the goals set will not work, this is due to teachers who have a major influence on educational attainment from elementary school to tertiary education. A teacher is required to be disciplined, both disciplined in teaching, discipline in and out of school and disciplined in other activities. Then the teacher at work is not out of fear of the principal, but a teacher in teaching must be aware of his responsibilities.

In this case the headmaster has a sufficient role as: educator (educator), as a manager, as an administrator, as a leader (leader), and the principal acts as a supervisor. Because of that education supervision is needed to stabilize teacher performance. Because schools are functional teachers who are given the task to lead a school where teaching and learning processes are held or where interaction occurs between the teacher giving the lesson and the student receiving the lesson.

The objectives to be achieved are goals that are in accordance with established standards. Therefore, to guarantee the quality of teaching and learning services or good teacher performance, the supervision of the principal becomes important in providing guidance, guidance and supervision to the teacher. This supervision is important to do, because this educational supervision generally refers to efforts to improve the teaching and learning situation that will produce good quality education

Therefore as a supervisor, the principal is expected to be able to act as a consultant, as a facilitator who understands the needs of the teacher and is also able to provide alternative solutions. In addition, the principal is also expected to motivate teachers to be more creative and innovative.

In the context of fostering teacher competence through supervision activities, it is important to note that these activities not only focus on increasing knowledge and skills in managing learning, but also encourage the development of motivation to improve the quality of performance. Every element of the leadership should be able to move other people, both subordinates or colleagues, so that they are consciously willing to behave to achieve the goals set. Educational supervision activities are one way of fostering teachers, therefore the principal has a strategic position towards efforts to improve teacher performance.

Based on preliminary observations that researchers do that, there is a gap between expectations and reality in the implementation of supervision. This gap can be seen from the error in interpreting the nature and purpose of supervision. The purpose of supervision is to assist teachers in improving the learning process towards better, but the reality in practice in the field the supervisor is more emphasis on other aspects besides educating or teaching that is the responsibility in terms of teacher administration such as RPP, Syllabus and so forth. Or even 
vice versa, there are teachers who do not know that the principal is a supervisor at the school so that the teacher is not directed or less directed at carrying out their duties.

E. Mulyasa (2007: 111) states that supervision is a process specifically designed to assist teachers and supervisors in learning various kinds of daily tasks at school, so that they can use their knowledge and abilities to provide better services to parents of participants students and schools as effective learning communities.

To be able to achieve the successful implementation of this supervision there are several things that become a problem, including teachers lacking in delivering material in teaching and learning activities, some teachers cannot use the media as a supporting tool and there are some teachers who do not want to use learning media for various reasons including: infocus only one is not enough for 40 more teachers, there are no computers or laptops in the school and the conditions of the room are cramped, the next problem is the incomplete teacher administration and because of the busy headmasters with activities outside of school such as invitations to official meetings which lead to a predetermined schedule for supervision becomes changed and it is difficult to get an appropriate schedule between the principal and the teacher. In this regard supervision is rarely carried out completely. In this study, effective supervisors are good principals. The principal is the center of leader in helping the effectiveness of teaching and learning (Lele, 2018).

\subsection{Significance of the study}

This research is an input for schools in Deli Serdang District to conduct continuous supervision. Furthermore, as a motivator in improving the performance of high school and vocational teachers in Deli Serdang Regency. It is expected to be able to broaden knowledge in the field of education, especially regarding the supervision of school principals, teacher performance and the effect of school supervision on the performance of high school / vocational teachers.

\subsection{Scope and Limitation of the study}

From the identification of the problems outlined above, this research will be limited to the implementation of the Supervision of School Principals on the Performance of SMA / SMK Teachers in Medan Sunggal District. 


\subsection{Setting of the study}

The location used as a research site is a public elementary school in Medan Sunggal, Deliserdang Regency, which amounts to 63 high schools. The school is spread in various villages in the region which consists of several sub-districts. Namely Rayon 2, 7, 10,11, 12, 13, 14 and 15.

\section{Research Design And Methodology}

This study uses existing data without providing treatment or manipulation of data on the variables studied, so that it is included in ex post facto research. This study revealed the facts based on the measurement of symptoms that had existed in the respondents. The analysis in this study uses quantitative analysis which uses numbers to summarize the results of the study

\subsection{Respondents of the study}

In this study the number of respondents was 292 high school / vocational school teachers spread over several locations in Medan Sunggal District and consisted of several sub-districts. School distribution data can be seen in the following table.

Table 1. Schools Name field of research

\begin{tabular}{|c|l|c|}
\hline NO & Schools Name & $\begin{array}{c}\text { Sub } \\
\text { Rayon }\end{array}$ \\
\hline 1 & SMA Negeri 1 Pancur Batu & 02 \\
\hline 2 & $\begin{array}{l}\text { SMA Swasta Era Utama } \\
\text { Pancur Batu }\end{array}$ & 02 \\
\hline 3 & $\begin{array}{l}\text { SMA Swasta Rakyat Pancur } \\
\text { Batu }\end{array}$ & 02 \\
\hline 4 & $\begin{array}{l}\text { SMA Swasta Methodist Pancur } \\
\text { Batu }\end{array}$ & 02 \\
\hline 5 & SMA Swasta Anastasia & 02 \\
\hline 6 & $\begin{array}{l}\text { SMA Negeri 1 Hamparan } \\
\text { Perak }\end{array}$ & 07 \\
\hline 7 & SMAS PAB 5 Klumpang & 07 \\
\hline 8 & SMAS Pelita Bulu Cina & 07 \\
\hline 9 & SMAS BPI Paluh Kurau & 07 \\
\hline 10 & SMAS Melati Hamparan Perak & 07 \\
\hline 11 & SMAS Harapan Paya Bakung & 07 \\
\hline
\end{tabular}




\begin{tabular}{|c|l|c|}
12 & SMAS Swadaya Bulu Cina & 07 \\
\hline 13 & SMAS Tarbiyah Islamiyah & 07 \\
\hline 14 & SMAS Al-FATTAH & 07 \\
\hline 15 & SMAS Delisha & 07 \\
\hline 16 & SMA Negeri 1 Sunggal & 10 \\
\hline 17 & SMA S Bayu Pertiwi & 10 \\
\hline 18 & $\begin{array}{l}\text { SMA S Muhammadiyah 18 } \\
\text { Sunggal }\end{array}$ & 10 \\
\hline 19 & $\begin{array}{l}\text { SMA S Ma'had Muhammad } \\
\text { Saman }\end{array}$ & 10 \\
\hline 20 & $\begin{array}{l}\text { SAM Swasta Rk Deli Murni } \\
\text { Diski }\end{array}$ & 10 \\
\hline 21 & SMA Nila Harapan & 10 \\
\hline 22 & SMA Swasta Prestasi Utama & 10 \\
\hline 23 & SMA Swasta Andreas & 10 \\
\hline 24 & SMA Swasta Valentine & 10 \\
\hline 25 & SMA Swasta Persiapan & 10 \\
\hline 26 & SMA It Jabal Noor & 10 \\
\hline 27 & SMA Swasta Amanah Tahfidz. & 10 \\
\hline 28 & SMA Negeri 1 Kutalimbaru & 11 \\
\hline 29 & SMAS Methodist kutalimbaru & 11 \\
\hline 30 & $\begin{array}{l}\text { SMA Galih Agung } \\
\text { Kutalimbaru }\end{array}$ & 11 \\
\hline 31 & $\begin{array}{l}\text { SMA Swasta YAPIM Sei } \\
\text { Glugur }\end{array}$ & 11 \\
\hline 32 & $\begin{array}{l}\text { SMASwasta Generus Bangsa } \\
\text { Kutalimbaru }\end{array}$ & 11 \\
\hline 33 & $\begin{array}{l}\text { SMA Swasta Rakyat Sei } \\
\text { Glugur }\end{array}$ & 11 \\
\hline 34 & SMA Negeri 1 Namorambe \\
\hline 35 & SMA S Darul Ilmi Murni & 12 \\
\hline 36 & SMA S Cerdas Bangsa & 12 \\
\hline 37 & SMA Yapim Namorambe & 12 \\
\hline 38 & SMA Masehi Namorambe & 12 \\
\hline 39 & SMA Negeri 1 Delitua & 13 \\
\hline 40 & SMA Swasta Harapan 3 & 13 \\
\hline 41 & SMA Swasta Istiqlal Delitua & 13 \\
\hline & SMA Swasta Singosari Delitua & 13 \\
\hline
\end{tabular}




\begin{tabular}{|c|l|c|}
43 & SMA Swasta YPI Delitua & 13 \\
\hline 44 & $\begin{array}{l}\text { SMA Swasta RK Deli Murni } \\
\text { Delitua }\end{array}$ & 13 \\
\hline 45 & SMA Swasta Delitua School & 13 \\
\hline 46 & $\begin{array}{l}\text { SMA Swasta Karya } \\
\text { Pembangunan Delitua }\end{array}$ & 13 \\
\hline 47 & $\begin{array}{l}\text { SMA Swasta YAPIM Biru- } \\
\text { Biru }\end{array}$ & 13 \\
\hline 48 & SMA Swasta Barma Biru-Biru & 13 \\
\hline 49 & $\begin{array}{l}\text { SMA Swasta Karya Sedar } \\
\text { Biru-Biru }\end{array}$ & 13 \\
\hline 50 & $\begin{array}{l}\text { SMA Swasta Masehi Biru- } \\
\text { Biru }\end{array}$ & 13 \\
\hline 51 & SMA Swasta PAB 9 Patumbak & 13 \\
\hline 52 & $\begin{array}{l}\text { SMA Swasta Unggulan Ummu } \\
\text { Rahma Patumbak }\end{array}$ & 13 \\
\hline 53 & $\begin{array}{l}\text { SMA Swasta Al Husna } \\
\text { Patumbak }\end{array}$ & 13 \\
\hline 53 & $\begin{array}{l}\text { SMA Swasta Rizki Ananda } \\
\text { Patumbak }\end{array}$ & 13 \\
\hline 55 & $\begin{array}{l}\text { SMA Swasta Karya Utama } \\
\text { Patumbak }\end{array}$ & 13 \\
\hline 56 & SMA Negeri 1 Sibolangit & 14 \\
\hline 57 & $\begin{array}{l}\text { SAM S Rk Deli Murni Bandar } \\
\text { Baru }\end{array}$ & 14 \\
\hline 58 & SMA N 1 Labuhan Deli & 15 \\
\hline 59 & SMA Swasta PAB-6 Helvetia \\
\hline 60 & $\begin{array}{l}\text { SMA Swasta Pangeran } \\
\text { Antasari }\end{array}$ & 15 \\
\hline 61 & SMA Swasta Sinar Husni \\
\hline 62 & $\begin{array}{l}\text { SMA Swasta Unggulan Ct } \\
\text { Foundation }\end{array}$ \\
\hline 63 & SMA Swasta Kingston & 15 \\
\hline & & 15 \\
\hline
\end{tabular}

\subsection{Research Instrument}

In this study, the instruments used were questionnaires or questionnaires, documentation, and unstructured interview guidelines. The research instrument was in the form of a questionnaire. The data generated from the distribution of this questionnaire had an ordinal measurement scale 
considering that the questionnaire was distributed using a Likert scale with a range of 1-4 with alternative answer choices.

\subsection{Data Gathering Procedure}

In this study, data collection using a questionnaire / questionnaire. For more details described as follows. The data in this study are primary data that were revealed by spreading or giving questionnaires to school teachers in Medan Sunggal High School / Vocational School. The research questionnaire was in the form of a closed questionnaire to reveal the supervision of principals $(\mathrm{X})$ and teacher performance $(\mathrm{Y})$.

\subsection{Statistical Analysis}

In this study the validity test used is content validity, i.e. the extent to which the items in the questionnaire represent the components in the entire content area of the object to be measured (representative aspects) and the extent to which the items in the questionnaire reflect the characteristics of the actors to be measured (aspects of relevance). Item analysis was performed using the Pearson product moment correlation formula method. In this study the reliability testing technique on instruments with stratified scores namely on the principal's supervision instruments and teacher performance using the Alpha formula (Sugiyono, 2012).

$$
\mathrm{r} 11 \frac{k}{k-1} \quad 1-\frac{\sum \sigma b 2}{\sigma t 2}
$$

\section{Findings and Conclusions}

Supervision of School Principals in Menenagah Atas and vocational schools in Medan Sunggal District, Delis Serdang Regency, North Sumatra. The data in this study were obtained using two data collection techniques, which include a questionnaire addressed to 74 teachers and supported using unstructured observation techniques. There are 3 indicators to determine the supervision of elementary school principals in Sunggal District, namely through learning planning, learning implementation and learning evaluation. The results of the descriptive analysis are as follows 
Table 1. Recapitulation of the Achievement of Each Indicator in Supervision Implementation

\begin{tabular}{|c|c|c|c|c|}
\hline No & $\begin{array}{c}\text { Item } \\
\text { Indicator } \\
\text { Statement }\end{array}$ & $\begin{array}{l}\text { Value's } \\
\text { Average }\end{array}$ & $\begin{array}{l}\text { Avera } \\
\text { ge }\end{array}$ & $\begin{array}{l}\text { Classific } \\
\text { ation } \\
\text { Points }\end{array}$ \\
\hline 1 & $\begin{array}{l}\text { teaching } \\
\text { preparation }\end{array}$ & $1,2,3,4,5,6,7$ & 2,61 & Good \\
\hline 2 & $\begin{array}{l}\text { Use of } \\
\text { methods and } \\
\text { instruments }\end{array}$ & $\begin{array}{c}8,9,10,11,12 \\
13,14,15 \\
, 16,17,18,20 \\
21\end{array}$ & 2,57 & Good \\
\hline 3 & $\begin{array}{l}\text { Determinati } \\
\text { on of } \\
\text { procedures } \\
\text { and use of } \\
\text { evaluation } \\
\text { results }\end{array}$ & $\begin{array}{c}22,23,24,25 \\
26,27\end{array}$ & 2,50 & Good \\
\hline \multicolumn{3}{|c|}{ Total Average } & 2,56 & Good \\
\hline
\end{tabular}

Based on the data in the recapitulation table above, it can be seen that the achievement of each indicator of the supervision of school principals, namely: 1) teaching preparation is classified as "good" with an average achievement of 2.61.2) the use of methods and instruments is classified as "good" with the achievement of an average value of 2.57. 3) determining the procedure and utilizing the results of the evaluation are classified as "good" with an average achievement of 2.50. Overall the supervision of principals is included in the classification of "good" with an average value of 2.56 .

Table 2. Teacher Performance in SMA / SMK in Medan Sunggal District

\begin{tabular}{|c|l|c|c|c|}
\hline No. & \multicolumn{1}{|c|}{$\begin{array}{c}\text { Indicator Item } \\
\text { statement }\end{array}$} & Average Value & $\begin{array}{c}\text { Aver } \\
\text { age }\end{array}$ & $\begin{array}{c}\text { Classific } \\
\text { ation } \\
\text { Points }\end{array}$ \\
\hline 1 & $\begin{array}{l}\text { Preparation of } \\
\text { Syllabus and RPP }\end{array}$ & $\begin{array}{c}1,2,3,4,5,6,7,8,9, \\
10,11\end{array}$ & 2,59 & Good \\
\hline 2 & Open Learning & 12,13 & 2,50 & Good \\
\hline 3 & Learning process & $\begin{array}{c}14,15,16,17,18,1 \\
9,20,21,2 \\
2,23,24,25,26,27 \\
, 28,29\end{array}$ & 2,32 & Good \\
\hline 4 & Closing Learning & $30,31,32$ & 2,35 & Good \\
\hline 5 & Evaluation of & $33,34,35,36$ & 2,49 & Good \\
\hline
\end{tabular}




\begin{tabular}{|c|l|c|c|c|}
\hline & $\begin{array}{l}\text { Learning Process } \\
\text { Outcomes }\end{array}$ & & & \\
\hline 6 & $\begin{array}{l}\text { Learning } \\
\text { Evaluation }\end{array}$ & $37,38,39$ & 2,09 & Good \\
\hline \multicolumn{2}{|c|}{ Total Average } & 2,40 & Good \\
\hline
\end{tabular}

Based on the data in the recapitulation table above, it can be seen that the achievement of each teacher performance indicator namely:

- syllabus and lesson plans are classified as "good" classification with an average achievement of 2.59 .

- open learning classified in the classification of "good" with the achievement of the average value of 2.50 .

- the learning process is classified as "good" classification with an average achievement of 2.32 .

- closure of learning is classified as "good" classification with average achievement of 2.35 .

- evaluation of the results of the learning process classified as "good" classification with the achievement of the average value of 2.49 .

- learning evaluation is classified as "good" classification with average achievement of 2.09 .

- Overall achievement of the implementation of teacher performance included in the category of "good" with an average achievement of 2.40

TABLE 3. Supervision of School Principals in Fostering the Performance of SMA/SMK Teachers in Medan Sunggal District

\begin{tabular}{|c|c|l|}
\hline No & $\begin{array}{c}\text { Aspects } \\
\text { observed }\end{array}$ & \multicolumn{1}{|c|}{ Explanation } \\
\hline 1 & $\begin{array}{c}\text { Headmaster's } \\
\text { presence }\end{array}$ & $\begin{array}{l}\text { Timeliness of school principals } \\
\text { coming to work is very important } \\
\text { and must be considered by the } \\
\text { school principal himself. }\end{array}$ \\
\hline 2 & $\begin{array}{c}\text { Work } \\
\text { motivation }\end{array}$ & $\begin{array}{l}\text { The principal gives motivation to } \\
\text { the teacher, both motivation to the } \\
\text { problematic teacher and the teacher }\end{array}$ \\
\hline
\end{tabular}




\begin{tabular}{|c|c|c|}
\hline & & $\begin{array}{l}\text { whose performance has reached the } \\
\text { target. }\end{array}$ \\
\hline 3 & $\begin{array}{l}\text { Solution to } \\
\text { problem }\end{array}$ & $\begin{array}{l}\text { The headmaster asks each teacher } \\
\text { the complaints then the principal } \\
\text { offers an alternative solution to the } \\
\text { problem }\end{array}$ \\
\hline 4 & $\begin{array}{l}\text { Discussion } \\
\text { between the } \\
\text { principal and } \\
\text { the teacher }\end{array}$ & $\begin{array}{l}\text { The headmaster has a discussion } \\
\text { with the teacher so that the teacher } \\
\text { conveys the problems faced, } \\
\text { discussions or sharing. }\end{array}$ \\
\hline 5 & $\begin{array}{c}\text { Fostering } \\
\text { teacher } \\
\text { performance }\end{array}$ & $\begin{array}{l}\text { The principal conducts teacher } \\
\text { performance coaching that is } \\
\text { intended to measure the } \\
\text { performance of each teacher in } \\
\text { developing and improving the } \\
\text { quality of teaching, by providing } \\
\text { corrections and training so that the } \\
\text { teacher can further improve their } \\
\text { performance. }\end{array}$ \\
\hline 6 & $\begin{array}{l}\text { Do a good } \\
\text { job }\end{array}$ & $\begin{array}{l}\text { The principal gives direction and } \\
\text { guidance to the teachers so that the } \\
\text { teacher does the work well and on } \\
\text { time, then the principal gives a } \\
\text { good example to subordinates. The } \\
\text { principal acts as a figure, facilitator, } \\
\text { administrator and also as a } \\
\text { supervisor }\end{array}$ \\
\hline
\end{tabular}

The results of research in SMA / SMK Medan Sunggal Deliserdang District obtained from interviews to reveal the supervision of principals in fostering teacher performance by school principals are presented based on the definition of research concepts, namely: the discipline of principals and teachers, teachers doing their tasks properly and correctly (RPP), teacher readiness to teach, the suitability of the material with the syllabus, use of media, discussion activities, teacher opportunities to attend training, academic supervision activities, clinical supervision activities, obstacles in the implementation of academic supervision and obstacles in the implementation of clinical supervision in SMA/SMK Medan Sunggal District. And this study has the different with Janar research (Janar, 2010). 


\section{Conclution}

After conducting research and analyzing the results of the study, then there are three conclusions in accordance with the focus of research that can be taken in the study, namely:

a. Supervision of principals in high schools / vocational high schools in Medan Sunggal District which includes learning planning, learning implementation and learning evaluation is included in the "good" category with a mean value of 2.56 .

b. The performance of SMA/SMK teachers in the unified Medan sub-district which includes the preparation of syllabi and lesson plans, opening learning, learning processes, closing learning, evaluating learning outcomes, and evaluating learning (KBM) is included in the "good" category with a mean value of 2.40 .

c. Supervision of school principals in fostering teacher performance in SMA / SMK Se Medan Sunggal District, namely: first, supervision is carried out 2 times in one semester, namely at the beginning and at the end of the semester. Second, the type of supervision used is academic supervision and clinical supervision. Third, the techniques used are: class visit techniques, meetings with teachers, discussions, classroom observation techniques and private conversations with the teacher concerned who is called to the headmaster's room

\section{RECOMMENDATIONS}

Based on the above research conclusions, it is hereby recommended to school managers to remember the importance of the principal's educational supervision program on teacher performance. It is expected that policy makers will further socialize the purpose of supervision activities, so that the heads can improve teacher performance through supervision activities, especially at the high school and vocational level.

Principal, because this research shows that the supervision of the principal is very important in improving teacher performance in schools. Therefore the principal must improve the effectiveness of the implementation of the supervision so that teacher performance is improved.

\section{References}

Depdiknas .2003. Undang-undang RI No.20 tahun 2003.tentang sistem pendidikan nasional 
Mulyasa, E. 2007. Menjadi Guru Profesional menciptakan Pembelajaran Kreatif dan Menyenangkan. Bandung : Rosdakarya

David Moto Lele. 2018. Clinical Supervision Instrument Development for Junior High School Teacher Based on Android. Journal of Educational Research and Evaluation. JERE 7 (1) (2018) 94 - 100 [ONLINE] https://journal.unnes.ac.id > sju > index.php > jere > article > view

Sugiyono. (2012). Memahami Penelitian Kualitatif. Bandung: AlfaBeta.

Teta, Janar. (2011). Pengaruh Supervisi Kepala Sekolah Dan Fasilitas Mengajar Terhadap Kinerja Guru di SMA Negeri 2 Sukarjo Tahun Pelajaran 2010/2011. Surakarta: Universitas Sebelas Maret Surakarta. 